\title{
RISK FACTORS OF HYPERCHOLESTEROLEMIA ON OBESE PRE-ELDERLY POPULATION IN REJOSARI SUB-VILLAGE, GUNUNG KIDUL, YOGYAKARTA
}

\author{
Desto Arisandi ${ }^{1}$, Yesi Apriliasari ${ }^{1}$, Subrata Tri Widada ${ }^{2}$ \\ ${ }^{1}$ Program Studi D3 Analis Kesehatan, STIKes Guna Bangsa Yogyakarta \\ ${ }^{2}$ Program Studi D3 Analis Kesehatan Politeknik Kesehatan Kementerian Kesehatan \\ Yogyakarta \\ Email: destoarisandi.gby@gmail.com
}

\begin{abstract}
Background: Obesity is one of the most epidemiological burden which is being a dangerous threat for global health. It also contributes for leading cause of hypercholesterolemia. Prevalence of stroke, diabetes mellitus, coronary heart disease, and hypertension in Indonesia has reached out $23.7 \%$ in 2007 . Rejosari sub-village, Kemadang village, Tanjungsari subdistrict locate in coastal area which is fisher taking mostly part of the citizen's occupation. Hence they have tendency to intake sea products such as shrimps, squids, crabs, anchovies, and bivalves that contain amino acid required to growth and cell recovery nevertheless it also has much cholesterol contained which cause of total cholesterol level rising. The aims of this study to determine risk factors of hypercholesterolemia on obese pre-eldery population in Rejosari sub-village, Kemadang village, Tanjungsari sub-district, Gunung Kidul district, Yogyakarta.
\end{abstract}

Method: This was an analytic observational study with cross sectional that conducted on February 2015 on obese pre-eldery population in Rejosari sub-village, Kemadang village, Tanjungsari sub-district, Gunung Kidul district, Yogyakarta. Data collected such age, sex, blood pressure, seafood intake frequencies, and total cholesterol. Data were analyzed by STATA version 12 software for windows with spearman correlation statistical test.

Result: This study findings that 30 pre-elderly people came as respondents. Data performed the average value of age was 49 years old, systolic blood pressure was $142 \mathrm{mmHg}$, diastolic blood pressure was $87 \mathrm{mmHg}$, seafood intake frequencies was 3 times per week, and total cholesterol level was $241 \mathrm{mg} / \mathrm{dl}$. Spearman correlation shown age ( $p$ value $=0.0477$ ), systolic blood pressure ( $p$ value $=0.0012$ ), diasolic blood pressure $(p$ value $=0.0435$ ) and seafood intake frequencies ( $p$ value $=0.0018$ ) have stattistical correlation with hypercholesterolemia.

Conclusion:Age, systolic blood pressure, diastolic blood pressure, and seafood intake frequencies are correlated with total cholesterol raising within blood

Keyword: pre elderly, age, hypertension, seafood, hypercholesterolemia

\section{PENDAHULUAN}

Berdasarkan hasil Riset Kesehatan
Dasar Indonesia diketahui bahwa
prevalensi penyakit stroke, diabetes
militus, penyakit jantung, dan hipertensi di
Indonesia mencapai $23,7 \%$ pada tahun
2007 (Riskesdas, 2007). Salah satu faktor
penyakit stroke, DM dan penyakit jantung yang utama adalah dislipidemia yang ditandai dengan peningkatan kadar kolesterol total, kolesterol low density lipoprotein (LDL), trigliserida serta penurunan kadar high density lipoprotein (HDL). Dislipidemia merupakan kelainan metabolisme lipid yang ditandai dengan peningkatan maupun penurunan fraksi lipid. Salah satu kelainan fraksi lipid yang 
utama adalah kenaikan kadar kolesterol total atau hiperkolesterolemia (Almatsier, 2007). Faktor risiko yang dapat menyebabkan terjadinya hiperkolesterolemia meliputi genetik, usia, jenis kelamin, stres, indek masa tubuh, hipertensi, kebiasaan merokok, olah raga, dan pola makan yang kurang baik.

Penderita obesitas ditemukan lebih dari 1,4 miliar pada orang dewasa yang berusia di atas 20 tahun dan lebih banyak dialami oleh perempuan dibandingkan lakilaki. Prevalensi obesitas pada orang dewasa di Indonesia sebesar 4,7\% (Sudargo dkk., 2014). Obesitas merupakan kelebihan berat badan normal yang menjadi salah satu problem kesehatan masyarakat yang mempunyai dampak pada medis, psikis maupun sosial, tetapi juga berhubungan dengan kelangsungan hidup penderitanya. Menurut World Health Organization (WHO) seseorang disebut obesitas apabila memiliki nilai Indeks Massa Tubuh (IMT) lebih dari 25 $\mathrm{kg} / \mathrm{m}^{2}$ (Misnadiarly, 2007).

Obesitas berkaitan erat dengan peningkatan lemak di dalam tubuh. Penimbunan lemak pada dinding abdomen atau obesitas sentral menunjukan ada beberapa perubahan metabolisme, termasuk terhadap insulin dan meningkatnya produksi asam lemak bebas, dibandingkan dengan banyaknya lemak bawah kulit pada kaki dan lengan (Proverawati dan Asfuah, 2009). Penurunan metabolisme tubuh dan jumlah lemak di dalam tubuh yang bertambah banyak meningkatkan kolesterol dalam darah (hiperkolesterolemia) yang memicu terjadinya penyakit kardiovaskuler (Misnadiarly, 2007). Makanan yang mengandung lemak tinggi seperti makanan laut (seafood) yang dikonsumsi dapat menyebabkan timbunan lemak di dalam tubuh (Sitepoe, 1993; Almatsier, 2004).

Pralansia merupakan seseorang yang berusia antara 45-59 tahun. Semakin bertambah usia seseorang maka cenderung kehilangan massa otot dan mudah terjadi akumulasi lemak tubuh. Metabolisme di dalam tubuh juga akan menurun sehingga menyebabkan kebutuhan kalori yang diperlukan lebih rendah (Suiraoka, 2012).
Dusun Rejosari, Kemadang, Gunung Kidul merupakan daerah kawasan wisata pantai, sehingga masyarakat pada umumnya berprofesi sebagai nelayan, penjual ikan dan pengepul. Mengonsumsi makanan dari laut atau seafood sudah menjadi kebiasaan bagi masyarakat di daerah tersebut. Seafood merupakan salah satu makanan yang mengandung sumber protein tinggi yangmengandung semua asam amino esensial yang dibutuhkan oleh tubuh untuk pertumbuhan dan perbaikan sel, namun seafood mengandungan kolesterol yang tinggi sehingga konsumsi yang berlebihan memiliki risiko terhadap kejadian hiperkoleterolemia. Penelitian ini ingin mengetahui faktor risiko kejadian hiperkolesterolemia pada pralansia obesitas di Dusun Rejosari, Kemadang, Gunung Kidul, Yogyakarta.

\section{METODE PENELITIAN}

\section{Desain Penelitian}

Penelitian ini menggunakan jenis penelitian observasional analitik dengan rancangan cross sectional. Subjek pada penelitian yaitu pralansia obesitas di Dusun Rejosari, Kemadang, Gunung Kidul, Yogyakarta yang dilakukan pada bulan Februari 2015. Data penelitian diperoleh dari kuesioner meliputi: usia, tekanan darah sistol dan distol, indeks massa tubuh, kebiasaan mengkonsumsi seafood per minggu, serta kadar kolesterol darah puasa.

\section{Analisis Data Penelitian}

Analisis korelasi spearman digunakan untuk mengetahui faktor yang berhubungan terhadap kejadian hiperkolesterolemia menggunakan program STATA for Windows version 12.0 (Stata Corp LP., College Station, TX, USA) dengan confidence intervals $95 \%$.

\section{HASIL}

\section{Karakteristik Data Penelitian}

Subjek penelitian ini sebanyak 30 orang pralansia obesitas di Dusun Rejosari, Kemadang, Gunung Kidul, Yogyakarta. Rata-rata usia pralansia obesitas yaitu 49 tahun, tekanan darah 
sistol yaitu $142 \mathrm{mmHg}$, tekanan darah diatol yaitu $87 \mathrm{mmHg}$, kebiasaan mengkonsumsi seafood sebanyak 3 kali per minggu, serta kadar kolesterol sebesar $241 \mathrm{mg} / \mathrm{dl}$ (Tabel 1.).

Tabel 1. Distribusi frekuensi karakteristik pralansia obesitas di Dusun Rejosari, Kemadang, Gunung Kidul, Yogyakarta, 2015

\begin{tabular}{lrrrrr}
\hline \multicolumn{1}{c}{ Karakteristik } & Minimum & Maksimum & Mean & Median & $\begin{array}{c}\text { Standar } \\
\text { Deviasi }\end{array}$ \\
\hline Usia (tahun) & 45 & 59 & 49 & 47 & 5,17 \\
Sistol (mmHg) & 100 & 200 & 142 & 140 & 28,25 \\
Diastol (mmHg) & 60 & 100 & 87 & 90 & 10,49 \\
Konsumsi seafood (per/minggu) & 1 & 7 & 3 & 2 & 2,53 \\
Kadar Kolesterol (mg/dl) & 101 & 367 & 241 & 240 & 66,69 \\
\hline
\end{tabular}

\section{Analisis Korelasi Spearman}

Analisis bivariat faktor risiko hiperkolesterolemia dilakukan menggunakan uji statistik korelasi spearman karena data yang diperoleh merupakan data kontinu, namun tidak berdistribusi normal dengan tingkat kesalahan ( $\alpha$ ) sebesar 0,05 . Hasil analisis menunjukkan nilai $p$ value hitung lebih kecil dari a yang ditetapkan sehingga hipotesis null $(\mathrm{Ho})$ ditolak.

Nilai koefisien korelasi spearman ( $r$ ) untuk variabel usia dan tekanan darah diastol menunjukkan nilai hubungan yang cukup kuat $(0,3<|r|>0,5)$ dan bernilai positif. Interpretasi hasil analisis bivariat yaitu terdapat hubungan yang cukup kuat antara usia dan tekanan darah diastol dengan kejadian hiperkolesterolemia pada pralansia obesitas di Dusun Rejosari, Kemadang, Gunung Kidul, Yogyakarta, dimana semakin tinggi nilai usia dan tekanan darah diastol maka akan seiring dengan meningkatnya kadar kolesterol total di dalam darah. Nilai koefisien korelasi spearman (r) untuk variabel tekanan darah sistol dan kebiasaan mengkonsumsi seafood per minggu menunjukkan nilai hubungan yang sangat kuat $(/ \mathrm{r} />0,5)$ dan bernilai positif. Interpretasi hasil analisis bivariat yaitu terdapat hubungan yang kuat antara tekanan darah sistol dan kebiasaan mengkonsumsi seafood per minggu dengan kejadian hiperkolesterolemia pada pralansia obesitas di Dusun Rejosari, Kemadang, Gunung Kidul, Yogyakarta, dimana semakin tinggi nilai tekanan darah sistol dan kebiasaan mengkonsumsi seafood per minggu maka akan seiring dengan meningkatnya kadar kolesterol total di dalam darah (Tabel 2).

Tabel 2. Analisis korelasi spearman faktor risiko hiperkolesterolemia pada pralansia obesitas di Dusun Rejosari, Kemadang, Gunung Kidul, Yogyakarta, 2015

\begin{tabular}{lcc}
\multicolumn{1}{c}{ Karakteristik } & \multicolumn{2}{c}{ Analisis Bivariat } \\
\cline { 2 - 3 } & $\boldsymbol{r}$ & $\boldsymbol{p}$-value \\
\hline Usia & 0,36 & 0,0477 \\
Tekanan Darah Sistol & 0,56 & 0,0012 \\
Tekanan Darah Diastol & 0,37 & 0,0435 \\
Kebiasaan Mengkonsumsi seafood (per minggu) & 0,54 & 0,0018 \\
\hline
\end{tabular}

\section{PEMBAHASAN}

Kolesterol adalah salah satu jenis lemak dalam tubuh yang ditemukan di membran sel dari jaringan yang berguna untuk pembentukan sel, berbagai hormon, dan sebagai pengangkut fosfolipid, trigliserol, dan banyak mikronutrien penting seperti $\beta$-karoten dan vitamin E (Zang dan Muldoon, 2004).Kolesterol di dalam tubuh terutama diperoleh dari hasil sintesis di dalam hati.Bahan bakunya diperoleh dari karbohidrat, protein atau lemak.Jumlah yang disintesis tergantung pada kebutuhan tubuh dan jumlah diperoleh dari makanan (Almatsier, 2004). 
Hiperkolesterolemia merupakan kondisi dislipidemia yang ditunjukkan melalui adanya kenaikan kadar kolesterol di dalam darah. Kriteria yang ditetapkan oleh konsensus nasional pengelolaan dislipidemia Indonesia mengenai kategori dislipidemia yaitu apabila seseoarang memiliki kadar kolesterol total di dalam darah > 200mg/dl (Sudoyo dkk., 2006). Hiperkolesterolemia merupakan salah satu faktor risiko terjadinya penyakit jantung, DM, stroke, dan hipertensi (Almatsier, 2007).

Perkembangan berat badan memiliki hubungan yang linier dengan pertumbuhan tinggi badan dengan kecepatan tertentu. Indeks massa tubuh merupakan salah satu indikator untuk menilai status gizi seseorang (Anggraeni, 2012). Obesitas atau yang biasa dikenal dengan kegemukan merupakan istilah yang digunakan untuk menunjukkan adanya penumpukan lemak tubuh (jaringan adipose) secara berlebihan yang melebihi batas normal (Suiraoka, 2012).Obesitas terjadi akibat ketidakseimbangan energi yang masuk melebihi energi yang dikeluarkan dalam jangka waktu tertentu (Soegondo dan Gustaviana, 2007). Timbunan lemak yang tinggi dapat menyebabkan meningkatnya penyerapan sel terhadap asam lemak bebas dan memicu oksidasi lemak, sehingga dapat menghambat penggunaan glukosa dalam otot untuk diubah menjadi energi (Suiraoka, 2012).

Aktivitas fisik yang kurang dapat menyebabkan pembakaran energi oleh tubuh berkurang, sehingga kelebihan energi dalam tubuh akan disimpan dalam bentuk lemak di dalam tubuh (Proverawati, 2010). Lemak yang diserap dari makanan dan lipid yang disintesis oleh hati dan jaringan adiposa harus diangkut ke berbagai jaringan dan organ untuk digunakan dan disimpan. Asupan makanan berlebihan dan penurunan pengeluaran energi menyebabkan akumulasi lemak berlebihan di jaringan adiposa abdominal Murray, dkk., 2009).

Peningkatan risiko hiperkolesterolemia relatif seiring dengan peningkatan usia, khususnya pada usia lebih dari 40 tahun. Hal ini disebabkan karena semakin bertambahnya usia seseorang maka cenderung kehilangan massa otot dan mudah terjadi akumulasi lemak di dalam tubuh, serta metabolisme di dalam tubuh menjadi menurun sehingga menyebabkan kebutuhan kalori yang diperlukan menjadi lebih rendah (Suiraoka, 2012). Peningkatan kadar kolesterol pada usia lanjut dapat juga disebabkan oleh aktivitas reseptor LDL semakin berkurang. Sel reseptor ini berfungsi sebagai hemostasis pengatur peredaran kolesterol dalam darah dan banyak terdapat dalam hati, kelenjar gonad, dan kelenjar adrenal. Kolesterol akan meningkat dalam sirkulasi darah jika sel reseptor ini terganggu (Heslet, 1997). Hasil penelitian diketahui bahwa semakin bertambahnya usia berhubungan terhadap peningkatan kadar kolesterol di dalam darah $(p=0,03)$. Hasil ini sejalan dengan penelitian yang dilakukan oleh Hartini (2009) yang menyatakan bahwa semakin bertambah usia seseorang, maka kadar kolesterol juga semakin meningkat.

Hipertensi merupakan meningkatnya tekanan darah di dalam arteri yang dapat menyebabkan peningkatan risiko terhadap penyakit stroke, jantung dan kerusakan ginjal.Tekanan yang abnormal tinggi di dalam arteri menyebabkan meningkatnya risiko terhadap stroke, jantung dan kerusakan ginjal. Hipertensi berhubungan dengan abnormalitas lipid kolesterol total dan dislipidemia meningkatkan risiko terjadinya hipertensi sehingga dapat meningkatkan risiko penyakit yang berkaitan dengan kardiovaskuler (Sunaryati, 2011).

Kelainan pembuluh darah seperti penyempitan pembuluh darah juga sering ditemukan pada usia lanjut. Hal tersebut berhubungan dengan diferensiasi yang terjadi seperti pada dinding dalam pembuluh darah, misalnya arteri yang kehilangan elastisitas secara bertahap secara progresif dalam waktu yang cukup lama. Dampak dari menurunnya fungsi arteri ini dapat terlihat mulai dari usia pertengahan (25-40 tahun) sampai tua (4060 tahun). Penurunan fungsi ini terjadi karena ini dikarenakan adanya pengendapan lemak di dalam pembuluh darah (Baraas, 1996).Hipertensi sangat berpengaruh terhadap peningkatan kadar kolesterol di dalam darah. Hal ini dapat 
dilihat bahwa masyarakat yang memiliki tekanan darah sistolik dan diastolik yang tinggi masing-masing sebanyak $63 \%$ dan $47 \%$. Penelitian yang sama dilakukan oleh Margarita, dkk. (2013) dengan hasil menyatakan bahwa kadar kolesterol yang tinggi seiring dengan peningkatan tekanan darah.

Mengonsumsi makanan yang mengandung lemak dapat membuat tubuh semakin mudah terserang penyakit dan mengalami banyak keluhan gangguan kesehatan. Konsumsi makanan yang tinggi lemak atau lemak jenuh yang tinggi akan membawa dampak buruk bagi kesehatan salah satunya adalah meningkatkan kadar kolesterol dalam tubuh (Sitopue, 1992). Pralansia obesitas yang mengkosumsi seafood 3-4 kali dalam seminggu memiliki kadar kolesterol tinggi paling besar yakni sebanyak $88 \%$. Hasil penelitian ini sejalan dengan Adhiyani (2011) yang membuktikan bahwa asupan kolesterol yang berlebih dalam tubuh mempengaruhi peningkatan kadar kolesterol darah.

\section{KESIMPULAN}

Usia, tekanan darah sistol dan diastol serta kebiasaan mengkonsumsi seafood berhubungan terhadap peningkat-an kadar kolesterol di dalam darah, sehingga program diit konsumsi makanan yang mengandung lemak tinggi seperti udang, cumi, kepiting dapat merupakan usaha pencegahan terhadap kejadian hiperkolesterolemia.

\section{DAFTAR PUSTAKA}

Adhiyani C. 2011. Hubungan Usia dan Konsumsi Makanan Berlemak dengan Kolesterol Total pada Lansia di Kelurahan Serengan Surakarta. Karya Tulis IImiah. Akademi Analis Kesehatan Surakarta.

Almatsier S. 2004. Prinsip Dasar IImu Gizi. Gramedia Pustaka Utama. Jakarta.

Almatsier S., 2007, Penuntun Diet, Gramedia Pustaka Utama, Jakarta.

Anggraeni, A.C. 2012. Nutrition Care Proces. Graha Ilmu. Yogyakarta.

Baraas, F. 1996.Mencegah Serangan Jantung Dengan Menekan
Kolesterol. PT Gramedia Pustaka. Jakarta.

Hartini S. 2009. Efektivitas Senam Lansia Terhadap Penurunan Kadar Kolesterol Darah pada Lansia Terhadap Merokok di Dusun Pirak Mertosutan Sidoluhur Godean Sleman Yogyakarta Tahun. Karya Tulis IImiah. Prodi S-1 Keperawatan STIKes Kusuma Husada Surakarta.

Heslet, L. 1997. Kolesterol Yang Perlu Anda Ketahui, Kesaint Blanc, Jakarta.

Khairani R., Sumiera M. 2005. Profil Lipid pada Penduduk Lanjut Usia di Jakarta. Universa Medicina. Volume 24, No. 4, OktoberDesember2005.

Margarita, Princen, Andi, Rumawas, Kidarsa dan Sutrisna. 2013. Kadar Kolesterol Total dan Tekanan Darah Orang Dewasa Indonesia. Jurnal Kesehatan Masyarakat Nasional Volume. 8, No. 2, September 2013.

Misnadiarly. 2007. Rematik Asam Urat, Hiperurisemia, Arthritis Gout. Pustaka Obor Populer. Jakarta.

Murray, RK., Granner DK., dan Rodwell, VW. 2009. Biokimia Harper, edisi 27, EGC. Jakarta.

Proverawati A. 2010. Obesitas dan Gangguan Perilaku Makan pada Remaja. Nuha Medika, Yogyakarta.

Proverawati, A., Asfuah, S., 2009, Gizi untuk Kebidanan, Edisi I, Nuha Medika, Yogyakarta.

Riskesdas. 2008. Laporan Riset Kesehatan Dasar 2007. Badan Penelitian dan Pengembangan Kesehatan Kementrian Kesehatan Republik Indonesia.

Sitepoe M. 1993. Kolesterol Fobia. Gramedia Pustaka Utama. Jakarta.

Soegondo, S., Gustaviana, R., 2007.Buku Ajar IImu Penyakit Dalam. Departemen IImu Penyakit Dalam FK UI, Jakarta.

Sudargo T, Harry FLM, Felicia L, Nur AK. 2014. Pola Makan dan Obesitas.Gadjah Mada University Press. Yogyakarta.

Sudoyo AW, Setiyohadi B, Alwi I, Simadibrata M, Setiati S. 2006. 
Buku Ajar Penyakit Dalam Edisi 4. Interna Publishing. Jakarta.

Suiraoka I P. 2012. Penyakit Degeneratif. Nuha Medika, Yogyakarta.

Sunaryati SS. 2011. 14 Penyakit Paling Sering Menyerang dan Mematikan.Flashbook. Yogyakarta.

Waluyo T. 2013. Hubungan Antara Konsumsi Pangan dan Aktivitas Fisik dengan Kadar Kolesterol
Darah pada Pria dan Wanita Dewasa di Bogor. Jurnal of General Physiology (JGP), Volume 8, Nomor 1, Maret 2013.

Zang, J.,Muldoon, R.E., 2004, Serum Cholesterol Concentration are Associated with Visumotor Speed in Men, Finding Form The Third National Health and Nutrition Examination Survey. Pp291-29. 